\title{
Study on the Driving Factors of Economic Growth in Shanxi Province
}

\author{
$\mathrm{Li} \mathrm{Li}^{1,}$, Dongyang $\mathrm{Pan}^{2}$, b , Chunyan $\mathrm{Si}^{3}$ \\ ${ }^{1}$ School of Public Policy and Management, Tsinghua University, Beijing, 100084, China \\ ${ }^{2}$ Central University of Finance and Economics, Beijing, 100081, China \\ 3 China University of Geosciences, Beijing, 100083, China \\ aE-Mail: lilyght@126.com, ${ }^{\mathrm{b}}$ E-Mail:ppddyy@gmail.com
}

Keywords:Economic growth,Industrial structure effect,Demand dynamic effect,Endowments dynamic effect, Granger causality test

\begin{abstract}
At present, the macroeconomic situation in Shanxi province is complicated and the economy downtown pressure is increasing. Based on this background, this paper investigates the relationships between the industrial structure effect and economic growth, demand driving effect and economic growth, endowments driving effect and economic growth in Shanxi province using Granger causality test and the data during the period from 1978 to 2011.
\end{abstract}

\section{Introduction}

Mining economic region Shanxi province is rich in coal resource and has rapid economic growthfrom 1990s, while it fluctuated bigger in recent years because of the declining in coal price. GDP of Shanxi province was 1260.2 billion yuan in 2013, the growth rate was only $8.9 \%$ ranking $23^{\text {th }}$ in China. GDP was 1275.9 billion yuan in 2014 , the growth rate was only $4.9 \%$ ranking $31^{\text {st }}$ in China, namely the last one in the nationwide.Economic growth, especially long-term sustained and healthy economic growth, is not easy to achieve. Why is it hard to achieve a long-term sustainable and healthy economic growth, and what kind of power or mechanism can promote economic growth, for a typical mining economic region, Shanxi province needs to study the problem further. The paper utilizes Granger causality test to verify the factors driving the economic growth of Shanxi province, and provides reference for it to re-energize its economy.

\section{Literature Review}

The relationship between industrial structure and economic growth is always a hot issue in the study of economics. Based on the basic research of Fisher, Clark summarized the relation between industrial structure and economic growth in 1940. The results showed that the economy development progressed from agricultural society to industrial society and then to service industry in general, which was known as a "petty Clark's law" [1]. Jiang Z mentioned American famous economist $\mathrm{H}$. Chenery used 51 different types of national economic data to analyze whether the internal structure of industry was in normal values in some situation in 1960 [2]. Dong X, Song S, $\mathrm{Zhu} \mathrm{H} \mathrm{[3]} \mathrm{used} \mathrm{panel} \mathrm{data} \mathrm{from} 31$ provinces in the past three decades to empirically examine the relationship between economic growth and industrial structure.

Barro,Sala-I-Martin used the panel data confirmed investment played an important role in increasing the yields of workers, thus it will have an impact on economic growth [4]. Zhang K, Liu $\mathrm{X}$ [5] constructed a macroeconomic model, discussed the demand in the role of economic growth. Wang Q., Huang C., Wu Y [6] discussed the motive source of economic growth in Anhui province. The results demonstrated that the effect of consumer demand in the growth of the tertiary industry output was the first, and the effect on the secondary industry was the second.

DjulaBorozan [7], Yris D. FondjaWandji [8] used VAR model, ARDL model, VECM model and Grainger causality test of different periods and different regions to test the relationship between energy consumption and economic growth. The results found with unidirectional or bidirectional Grainger causal relationship between energy consumption and economic growth. Mercan M, SezerS 
[9] found a positive relationship between education expenses and economic growth in the Turkish economy from 1970 to 2012.

\section{Experimental Section}

Granger causality test.If a time sery is generated by a stochastic process, thus it is assumed that every number in the time series $\left\{\mathrm{x}_{\mathrm{t}}\right\}(\mathrm{t}=1,2, \ldots)$ can be obtained randomly from a probability distribution. If the following conditions can be met:

The mean value $E\left(x_{t}\right)=\mu$, is a constant and hasn't any relationship with the time constant of $t$. The variance $\operatorname{Var}\left(\mathrm{x}_{t}\right)=\sigma^{2}$, is a constant and hasn't any relationship with the time constant of $\mathrm{t}$. The covariance $\operatorname{Cov}\left(\mathrm{x}_{t} \mathrm{x}_{t+k}\right)=y_{k}$, is a constant, which is only relevant to the time span $\mathrm{k}$ and hasn't any relationship with the time constant of $t$;

Thus it can be said that the random sequence is stable. If a time sery isn't stable, its mean value and variance will change with the time $t$. If changing such a sequence into stable sequence need to be differenced $d$ times, then this sequence is called the $d$ orderintegration and can be denoted as I (d).

Data.When studying on industrial structure effect, the paper uses the proportion of the employment number in the secondary industry accounting for the total employment and the output value of the secondary industry accounting for Shanxi's GDP to measure the industrial structure.The data come from Shanxi Statistical Yearbook 1978-2011.

\section{Results}

Industrial structure effect. Granger causality tests between GDP and IS1, GDP and IS2 are tested in table 1 in the following.

Table 1Granger Causality Test

\begin{tabular}{lll}
\hline Null Hypothesis & F-Statistic & Prob. \\
\hline IS1 doesn't Granger Cause GDP & 0.93142 & 0.4171 \\
GDP doesn't Granger Cause IS1 & 0.02379 & 0.9765 \\
IS2 doesn't Granger Cause GDP & 1.01184 & 0.0087 \\
GDP doesn't Granger Cause IS2 & 1.39293 & 0.0207 \\
\hline
\end{tabular}

Demand dynamic effect. Granger causality tests between GDP and investment demand (ID), GDP and consumption demand (CD), GDP and export-led (EL) are tested in table 2.

Table 2Granger Causality Test

\begin{tabular}{lll}
\hline Null Hypothesis & F-Statistic & Prob. \\
\hline ID doesn't Granger Cause GDP & 4.26331 & 0.0246 \\
GDP doesn't Granger Cause ID & 1.26589 & 0.2982 \\
CD doesn't Granger Cause GDP & 1.79499 & 0.1854 \\
GDP doesn't Granger Cause CD & 0.78301 & 0.4671 \\
EL doesn't Granger Cause GDP & 3.60014 & 0.0411 \\
GDP doesn't Granger Cause EL & 0.44646 & 0.6445 \\
\hline
\end{tabular}

Endowments dynamic effect.

(1) Financial development

Granger causality tests are tested in table 3 . 
Table 3 Granger Causality Test

\begin{tabular}{lll}
\hline Null Hypothesis & F-Statistic & Prob. \\
\hline FD doesn't Granger Cause GDP & 0.15491 & 0.8577 \\
GDP doesn't Granger Cause FD & 1.65560 & 0.2203 \\
FS doesn't Granger Cause GDP & 2.45306 & 0.1159 \\
GDP doesn't Granger Cause FS & 2.46675 & 0.1147 \\
FS doesn't Granger Cause GDP & 8.60275 & 0.0026 \\
GDP doesn't Granger Cause FS & 9.14300 & 0.0020 \\
\hline
\end{tabular}

(2) Capital formation

Granger causality test between GDP and CF is tested in table 4.

Table 4 Granger Causality Test

\begin{tabular}{lll}
\hline Null Hypothesis & F-Statistic & Prob. \\
\hline CF doesn't Granger Cause GDP & 0.98173 & 0.4028 \\
GDP doesn't Granger Cause CF & 2.76836 & 0.1027 \\
\hline
\end{tabular}

(3) Science technology and education

Granger causality tests are tested in table 5.

Table 5Granger Causality Test

\begin{tabular}{lll}
\hline Null Hypothesis & F-Statistic & Prob. \\
\hline SRE doesn't Granger Cause GDP & 2.19191 & 0.1423 \\
GDP doesn't Granger Cause SRE & 0.71761 & 0.5021 \\
SRN doesn't Granger Cause GDP & 1.30952 & 0.2958 \\
GDP doesn't Granger Cause SRN & 1.53746 & 0.2434 \\
EX doesn't Granger Cause GDP & 18.2429 & 0.6005 \\
GDP doesn't Granger Cause EX & 2.63820 & 0.1005 \\
CE doesn't Granger Cause GDP & 4.41472 & 0.0286 \\
GDP doesn't Granger Cause CE & 3.28430 & 0.0622
\end{tabular}

\section{Conclusions and Implications}

(1) In the development of coal industry in the future, if coal resource continues to play a role in promoting economic growth, Shanxi province shall continue to adjust its industrial structure reasonably, accelerate the development of new technology and promote clean coal technology, clean coal technology, coal chemical industry and other relating industries.

(2) In the demand dynamic effect, the changes in investment and export will bring changes in economic growth.At present, the economic environment isn't harmonious and the income is expected to decline, which has seriously restricted the other aspects of consumption. In order to promote Shanxi's economic growth, it needs to promote the increase in consumer demand vigorously.

(3) From endowments dynamic effect, it can be concluded that optimizing the financial structure, improving the education expenditure and enhancing the status and level of human resources rapidly can promote Shanxi's economic growth. 


\section{Acknowledgments}

The authors express their sincere thanks for the support from the National Natural Science Foundation of China under Grant No.71173200 and the support from the Development and Research Center of China Geological Survey under Grant No.1212011220302 and 12120114056601, Key Laboratory of Carrying Capacity Assessment for Resource and Environment, Ministry of Land and Resources (Chinese Academy of Land and Resource Economics, China University of Geosciences Beijing) under Grant No.CCA2015.08.

\section{References}

[1]Gong Y.J., Ying Q.J. Industrial structure and industrial policy, 1st ed; Shanghai Lixin Accounting press: Shanghai, China, 1999, pp. 8-9.

[2] Jiang Z. Research on industrial structure problems, 1st ed.; China Economics Publishing House: Beijing, China, 2004, pp. 9-11.

[3] Dong X, Song S, Zhu H. Industrial structure and economic fluctuation-Evidence from China. The Social Science Journal, 2011, 48(3),pp. 468-477.

[4]Barro R J, Sala-i-Martin X. Economic growth and convergence across the United States. Harvard University, UK, 081995.

[5] Zhang K, Liu X. Analysis on the economic growth path from the angle of demand. Economic science 2007, 4,pp.25-36.

[6] Wang Q., Huang C., Wu Y. An empirical study on the relationship between consumer demand and economic growth in Anhui province. Journal of Hefei University (SOCIAL SCIENCE EDITION),2011, 28 (3), pp. 84-88.

[7]DjulaBorozan. Exploring the relationship between energy consumption and GDP: Evidence from Croatia. Energy Policy, 2013,59,pp. 373-381.

[8]Yris D. FondjaWandji. Energy consumption and economic growth: Evidence from Cameroon. Energy Policy, 2013, 61,pp. 1295-1304.

[9]Mercan M, Sezer S. The Effect of Education Expenditure on Economic Growth: The Case of Turkey. Procedia-Social and Behavioral Sciences, 2014, 109,pp. 925-930. 